\title{
Research on the Organic Renewal of Urban Color Based on New Contextual-ism
}

\author{
Wenjuan Bian \\ School of Architecture and Urban Planning \\ Shen Zhen University \\ Shenzhen, China
}

\begin{abstract}
Urban color is an important part of the characteristic styles in cities. Our country has already entered a new round urban renewal peak, then, focus on the organic renovation of urban color. This paper is devoted to a study on the succession and transmutation of urban color, from urban cultural contextual-ism perspective. Through combined the new contextual-ism and urban color theories, set a new concept of "urban color contextual-ism", included the intension and extension, then, analysis of the formative factors, and the characteristics. Based on the integration of result, perfecting urban color research system, so that enhance integrity, organically, artistry character, and lead the organic renewal of urban color.
\end{abstract}

Keywords-urban color; new contextual-ism; urban color contextual-ism; organic renewal

\section{INTRODUCTION}

With the flourishing development of urban renewal in our country, new understanding of urban development has been formed in the academic circles. Because the definition of city in the past was mainly focused on physical point, while neglecting its "organic life attribute", thus cannot accurately recognize the urban characteristics, leading to a series of urban problems. Urban color, as an important branch of urban system, also has problem. The planning and control has been paid much attention to. The lack of interpretation of intrinsic organic life and the limitation of research perspective make the development of urban color into the period of stagnation. It can be reflected into the following aspects: First, rigid demolition methods lead to urban color fragmentation and inherent ecological disorder; Second, governed by control, the planning of urban color is passive in solving endless problems, and unable to meet the needs of rapid urban renewal development. Therefore, inherent organic characteristics of urban color will become an important issue of urban color development in the new era. According to the above research background, this paper has explored the organic updating of urban color on the basis of new contextual-ism that expounds the organic characteristics of the contextual system.

Research project on the introduction of new teacher of Shenzhen University (project number: 2016060)

Innovative Talents Project of Guangdong Province (Social Sciences)

\section{INTRODUCTION OF NEW CONTEXTUAL-ISM}

\section{A. Explanation of New Contextual-ism}

The origin of the word Context is linguistics category. It is a historical category that has developed in a particular space. The extension of it contains a wide range of content ${ }^{1}$, narrowly interpreted as cultural context. Context thinking has a long history. It was first used in architecture in China, and then gradually extended to city field. Due to the ambiguity and uncertainty to it, there was no deep research on it and no independent theoretical system, thus the development was slow. At the same time, it was applied in architecture, city and landscape. But context has been inherited by city. "Based on the specific situation in our country, the present context is drawing on the western context. With development and innovation, it has been interpreted from the view of Chinese culture with new cultural connotation. It not only represents the essence of the past but also points to the present vitality of the cultural genes, and concerns about the future potential of cultural innovation. In this way, a system engineer called "new contextual-ism" has been formed to spread and inherit Chinese culture $^{2}$. The focus of it is not the interface between old and new, but its connotation to realize sustainable development of city and find the regulation of the context evolution.

\section{B. Explanation of Urban Color Contextual-ism}

Color is a subsystem of context. They are closely related to each other. Research perspective has been based on the surface phenomenon for a long time, and methods are rather single, thus research on urban color is flat, one-sided and static Although the close relationship between urban color and context has long been recognized by theorists, there is no systematic study that combines them. With the gradual resolving of urban color issues, the limitation and blind spots in the development of urban color development has appeared. Therefore, starting from the continuity of the urban context, this paper combines the new contextual-ism with urban color theory and puts forward the concept of "urban color contextual-ism" to further elaborate the organic updating of it.

Tan Xia. Context heritage Carrier----A preliminary study on urban memory space [D]. Chongqing: Chongqing University, 2008

$$
\text { Sun Junqiao. To new contextual-ism [D]. Chongqing University, }
$$


"Color contextual-ism" was first put forwarded by Ximan, a famous Chinese color expert. It includes the color of the geographical environment and human environment, especially the color of soil and landform, which is a method for investigation in urban planning, and the study of nature, society, humanities and history contextual color genes. Dr. Wang Wei from Southeast University has further developed the meaning of "color contextual-ism", which is summarized as the color representation of all the elements and the logical relationship between them in the existing urban environment. It should be the background and the starting point of urban color planning. Based on the above research background, and through the induction and integration and innovation of urban color research results, combining with the new contextual-ism, the "urban color contextual-ism" is dynamic. Its development has the feature of time and space, criticality and integrity, etc. It is also an open and complex system with powerful hidden forces. In this way, the concept "urban color contextual-ism" has been raised: It not only includes the existing color and gene in urban geographical and human environment, but also the relationship between color and logic, as well as a urban color contextual-ism network with connotation, life, heritage and development on the basis of time longitudinal axis and space horizontal axis. The urban color contextual-ism has more connotation and deeper extension compared with the former one. In this way, new components and mechanism have been showed in a new aspect.

The color contextual-ism space-time frame in "Fig. 1" is the extension of the concept of "urban color contextual-ism". It explains the time and space latitude and longitude of the urban color composition. Because the urban color is in different geographical space, the color axis features show the different color contextual-ism characteristics and performance, color space-time framework explained the geographical distribution of color in the geographical space, meanwhile represent the changing and developing urban color in the time axis, which reflect the continuity, integrality and dynamic of urban color. It is helpful for the overall multidimensional and comprehensive study of the evolution of urban color, continuation of urban color genes and construction of a stable ecological order of urban color in the horizontal and vertical coordinates in the past, present and future to maintain its color order "homeostasis" 3 , and control macro-control urban color evolution trend.

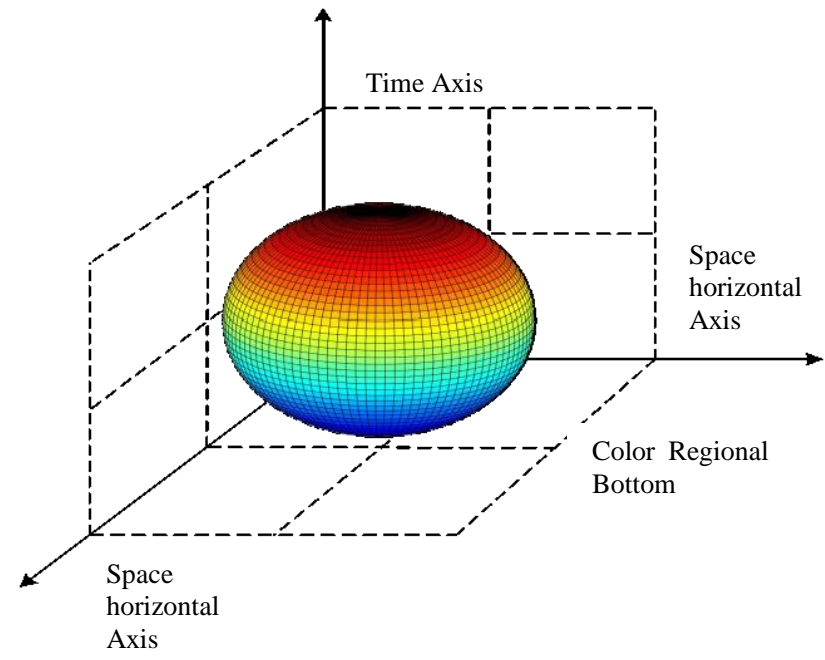

Fig. 1. Schematic diagram of the urban color contextual-ism space-time framework (Data Source: Applicant painting).

1) "Urban color contextual-ism" factors: The "urban color contextual-ism" as an organic continuum, inspired by the new contextual-ism, can introduce dominant and recessive genes in biogenetics ${ }^{4}$, and help analyze the evolving factors in the development of urban color in the process of "urban color contextual-ism".

a) Natural environment: The urban natural environment includes visible dominant factors such as regional climate, soil, hydrology, vegetation and landform. Among them, soil is the dominant factor of the most obvious connotation of urban color, because soil color is an important factor that cannot be neglected in city, architecture and environment. Secondly, the pristine soil directly determines the background color of the city. Therefore, natural environment determines the color of the city, and in the time dimension, help the formation of the urban network of color, and ultimately the formation of a city with regional characteristics. With modern rationalism and consumerism gradually leading the development of cities, urban natural environment has been neglected, and urban color genes have been gradually transformed and deconstructed. But it still exists in urban color development.

b) Human environment: City is the product of the accumulation of human culture. Urban human environment refers to the urban social environment with cultural accumulation as the background, material facilities as the carrier, interpersonal relationship and interpersonal relationship as the core. Overall, it is more complex, variable and malleable than natural environment. The urban natural environment is the natural material carrier of urban human environment, and the urban human environment is the soul that makes the whole city active. ${ }^{5}$ The natural colors of

4 Bian Wenjuan. Preliminary study on the inheritance of classical garden design techniques from the perspective of biological genetics [J]. Architecture and Culture. 2014 (10).

Zou Dongsheng, editor: Zhao Yunlin, Urban Ecology, China Agriculture Press, 2008.12, p73.
1932. Homeostasis: A biological definition refers to the ability that living things being able to maintain a constant internal state in response to changing external environment. 
architecture and environment are continuously changing by the influence of politics, religion, urbanization and national culture, So that the regional urban environment reflects its unique color and regional factor.

c) Ideology: Ideologically, the origin of development of "urban color contextual-ism", is the concept of collective unconscious created by Jung, a kind of natural deep unconscious. "The level of collective unconsciousness is unintentional, and it contains the experience accumulated by all generations in the past and even the ancestors." ${ }^{6}$ The root cause of its formation is the environment that a group of people or race live in, known as a social and cultural environment, including all indoor and outdoor artificial environment and natural environment. The fundamental feature of this environment is "Place Spirit" named by Schultz, which creates and continues the collective unconscious that exists in the deepest part of the human spirit. The traditional color ideology was formed in early time, and since then the reverence for life has resulted in the development of color cognition to the ideology of color symbols as totem worship. In the Xia and Shang Dynasties of Yangshao culture, color aesthetic psychology was gradually formed. In Zhou Dynasty, the simple materialistic worldview - "Five Elements" and five colors worship, the five worlds, earth god were combined together to form a set of time, space, human relations, rituals, called the "Five Elements of Color Science." In the Tang and Song dynasties, traditional "Five-Colored Aesthetics" was finally formed. Five colors referred to "red, yellow, blue, white and black", and "Pure Color" was regarded as auspicious. Nowadays, with the introduction of the rational western theory of color system, the traditional "Five Elements of Color Science" has gradually been neglected. Although the simple color concept does not form a color science system, the aesthetic consciousness of the five colors has been popular among the people and become the national feature of color.

2) Attribute of urban color contextual-ism: Based on the new contextual-ism and related attributes of urban color, the attributes of the urban color contextual-ism, such as holistic feature, dynamic feature and spontaneous feature are summed up.

a) Integrity: In the 1930s, Planck, founder of the famous quantum mechanics from Germany, said: "Science is an internal integrity. The separate parts does not depend on the essence of things, but on the limitations of human understanding." In the study of urban color, every part of the inheritance and mutation of information, have the overall meaning. The color of the different phases of the city evolves to form the urban color contextual-ism system, "Fig. 2" including the color of the past explaining by words, the color of the city based on urban chromatograms and databases, and the future urban color system.

Schultz. D. P. A History of Modern Psychology, translated by Yang Lineng, Chen Darou, Li Hansong.etc., 1981.

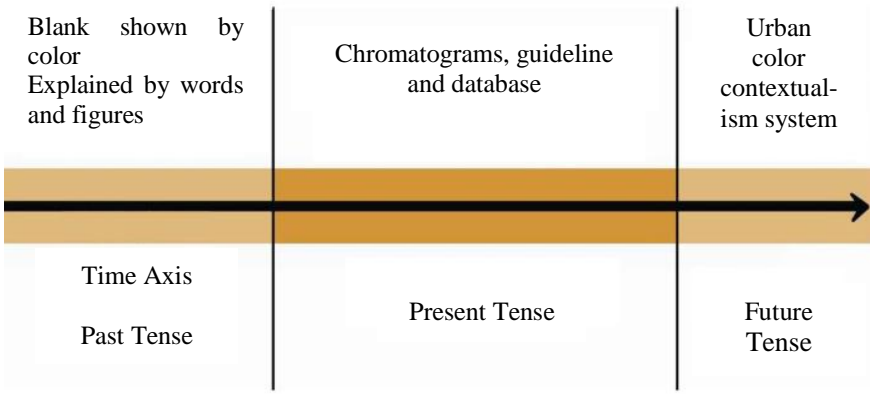

Fig. 2. Schematic diagram of urban color contextual-ism space-time system (Data Source: Applicant painting).

b) Spontaneous feature: The urban color contextual-ism is a complicated structure that reflects the balance and improvement of self-organizational and other organizational power. The collective unconscious traditional wisdom has made the "city color contextual-ism" an autonomous and spontaneous adjustment without the intervention and control of a specific external organizational system. Each unit appears to be disordered, in the accumulation of time dimension, the whole context contains invisible order and grows up in the control of powerful and invisible force. Maintaining the balance of inner color ecology is an advanced mechanism in the evolution and development of urban color. With the impact of globalization on tradition, the spontaneous nature of urban color has been gradually neglected or even excluded, and other organizational power breaks the self-organizational characteristics of urban color, blocks its own immune cells and causing the unbalanced development of urban color. Healthy and sustainable urban color system should be inherited, shaped, renewed and accumulated continuously.

c) Dynamic feature: On the study of the continuation and development of urban color, we should pay attention to its gradual evolution from a dynamic perspective rather than being rigid and stagnate at a certain node stage, so as to comprehensively and stereoscopically analyze the urban color development. Secondly, the urban color system itself is a living organism with continuous self-metabolism. A mechanism of mutual competition with the characteristic of interdependent, erosion, replacement, substitution, exclusion, grafting, and symbiosis has been formed with the specialty of continuous and rising trajectory, dynamic but not stationary, it is affecting the overall heritage and variation of urban color.

\section{CONCLUSION}

At present, the urban color renewal is in under fast development, yet due to the ambiguity of urban color and the slow development, urban color contextual-ism space-time framework should be formed to protect it, inherit its genes, enrich the connotation and promote urban organic renewal by respecting history, doing practice in current time and making plan for the future development. In this way, quality of urban color will be improved. Thus, overall, continuous, artistic and dynamic urban color style and feature will be presented. 


\section{REFERENCES}

[1] Galen Minah. Reading Form and Space; the Role of Color in the City.Architectural Design, 1996.37.

[2] Jean-Philippe Lenclos, Dominique Lenclos.Couleurs dumonde. Paris: Groupe Moniteur(Editions Le Moniteur), 1999.

[3] Ed taverne, The color of the city, Longman,1992,73.

[4] Gou A. A Study on the Method of Urban Color Plan Base onSpatial Configuration[J]. Color Research and Application , 2011:1-8.

[5] Gou A, Jiangbo W. Research on the Location Character ofUrban Color Plan in China[J]. Color Research and Application,2008(2): 68-76.

[6] Sun Junqiao. Go forward to the New Contextualism [D]. Chongqing University, 2010. 